\title{
French Teacher Shortages and Cultural Continuity in Alberta Districts, 1892-1940
}

\author{
Yvette T.M. Mahé
}

L'avenir national et pourtant religieux de nos enfants repose entre les mains de nos maîtres et maîtresses. Ils ont la lourde responsabilité de former les intelligences et les coeurs de plusieurs milliers de petits compatriotes sur lesquels les aînées fondent leurs espoirs de survivance franco-canadienne et catholique. ${ }^{1}$

Before francophones outside Quebec obtained the constitutional right to educate their children in French in the 1980s, and to manage their schools in the 1990s, cultural continuity in French-speaking communities depended on qualified bilingual or French-speaking teachers who were willing to resist schooling that conformed to Anglo-Canadian goals. ${ }^{2}$ After the state abolished confessional schooling and established a system of national schools in Manitoba in 1890, and in the Northwest Territories in 1892, francophones who were staunchly determined to preserve their language and culture viewed French-Canadian Catholic teachers as

1. Maurice Lavallée, "Les responsabilités des nos institueurs,” La Survivance (hereafter LS), 3 octobre 1934, 3.

2. Bernard Clavel et al., À la recherche d'une identité franco-ontarienne. La question scolaire (Montréal : Guérin, 1984); Monique Hébert, “ Vivre sa francophonie au temps de l'illégalité," in Francophonies plurielles, Gratien Allaire and Anne Gilbert, dir. (Sudbury: Institut Franco-Ontarien, 1998), 295-316; Raymond J. A. Huel, "L’enseignement du français dans les écoles publiques de la Saskatchewan: Une étrange dérogation aux dispositions de la Loi des Écoles dans l'Arrondissement scolaire d'Ethier No. 1834, 1921-1923,” in Perspectives sur la Saskatchewan, André Lalonde, Richard Lapointe, et Louis Julé, dir. (Régina : Société Historique de la Saskatchewan, 1983), 20218; Yvette T. M. Mahé, "Bilingual School Teachers' Cultural Mission and Practices in Alberta Before 1940,” Journal of Educational Thought 34, 2 (2000): 135-63; Isabelle McKee-Allain, "Une minorité et la construction de ses frontières identitaires : un bilan sociohistorique du système d'éducation en Acadie du Nouveau-Brunswick," Revue des sciences de l'éducation 23, 3 (1997) : 527-44.

(C) Historical Studies in Education/Revue d'histoire de l'éducation 14, 2 (2002): 219-46 
the key to their cultural survival. But, as this paper will show, such nationalistic teachers were scarce.

Raymond Huel explains that after the establishment of a system of national schools in the Prairie provinces in the 1890s, any attempts by European and French-speaking minorities to use public schools to preserve their language and culture "were viewed as treasonable acts because they threatened Canada's British character and institutions."3 Neil G. McDonald, who studied the development of public schooling in the Northwest Territories after 1892, concluded that Anglo-dominant prairie government policies and administrators "showed little sympathy or patience with the aspirations of a French-speaking Roman Catholic minority; nor an appreciation of the cultural and linguistic pluralism arising from the ethnic minorities that came to the North-West in the years immediately following this Anglo-Saxon ascendency."

Prior to consolidation of prairie school districts into large divisions, which took place in the 1930s and 1940s, ${ }^{5}$ district trustees had the power to hire teachers. But trustees in ethnic communities who wanted to retain their language and culture found that qualified teachers who could teach both English and the community's mother tongue were rare. ${ }^{6}$ The situation was no

3. Raymond Huel, "The Public School as Guardian of Anglo-Saxon Traditions: The Saskatchewan Experience, 1913-1918,” in Ethnic Canadians: Culture and Education, ed. M. L. Kovacs (Regina: Canadian Plains Research Center, University of Regina, 1978), 295-303.

4. Neil G. McDonald, "David J. Goggin: Promotor of National Schools,” in Shaping the Schools of the Canadian West, ed. David C. Jones, Nancy M. Sheehan, and Robert M. Stamp (Calgary: Detselig, 1979), 14-28.

5. F. Henry Johnson, A Brief History of Canadian Education (Toronto: McGraw-Hill Canada, 1968), 111-14.

6. For more information on trustees' experiences with the hiring of teachers in ethnic communities, see Marilyn Barber, "Canadianization Through the Schools of the Prairie Provinces Before World War I: The Attitudes and Aims of the English-Speaking Majority," in Ethnic Canadians: Culture and Education, ed. M. L. Kovacs, 281-94; Angela Gauthier, Nick Kach, and Kas Mazurek, "The Ruthenian School Revolt of 1913 : Linguistic and Cultural Conflict in Alberta," Historical Studies in Education 8, 2 (1996): 199-210; Cornelius J. Jaenen, "Ruthenian Schools in Western Canada 1879-1919,” in Shaping the Schools of the Canadian West, ed. David C. Jones et al., 39-58; Manoly Lupul, "The Schools and French- and Ukrainian-Language Claims in Alberta to 1918," in Exploring Our Educational Past, ed. Nick Kach and Kas Mazurek (Calgary: Detselig, 
different in the 118 school districts (hereafter referred to as bilingual or French districts) established by French-speaking settlers in Alberta between 1885 and 1939. When these districts were consolidated into 16 large divisions, ${ }^{7}$ they fell under the control of English-speaking administrators, and French district trustees lost their autonomy in the hiring of teachers. Furthermore, bilingual teachers continued to be scarce.

This article examines assimilationist language laws, teacher training institutions, bilingual schooling, teacher certification policies, and administrators' practices, all of which had an impact on the creation and maintenance of bilingual teacher shortages in Alberta before 1940. Other variables such as teacher workload, salaries, gender, and transiency are briefly touched upon. My primary focus is on the period before school district consolidation, but the legacy of French-language teacher shortages continues to this day.

\section{Language Laws, Teacher Training and Certification, and Cultural Uniformity}

After 1890, the state, with its juridical apparatus and administrators, effected institutional transformations to establish its legitimacy in society.

\section{Language Laws and Teacher Training}

Before the 1890s, French-speaking Catholics in the Prairies had the power to govern their schools and the right to instruct their children in French. French-Canadian teachers were prepared in

1992), 73-92.

7. For descriptive information on the names of the 118 districts, dates erected, their geographic location, trustees, and consolidation, see Yvette T. M. Mahé, School Districts Established by French-Speaking Settlers in Alberta: 1885-1939. Identification of Bilingual School Districts, vol. I (Edmonton: Faculté Saint-Jean, University of Alberta, 1989). 
Catholic institutions, ${ }^{8}$ and they were allowed to write their certification exams in French. ${ }^{9}$ After 1890, aspiring teachers had to attend a provincial normal school or university before they could be certified to teach. These institutions, however, did not prepare them to teach in a language other than English.

In 1896, the Manitoba government passed legislation to permit the teaching of French or a language other than English in public schools. Subsequently, a French normal school was opened in Saint-Boniface, followed by the opening of German, Ukrainian, and Polish teacher training centres. Fearing the Balkanization of their society, Anglo-Protestants pressured the government to abolish bilingual education. In 1916, legislation was passed to prohibit the teaching of all languages other than English in public schools, and all bilingual teacher training centres were closed. ${ }^{10}$

In 1892, the Northwest Territories government legislated English as the language of schooling. At the same time an ordinance was passed to permit trustees in French-speaking districts to offer a primary course in French. In 1901, the Territorial government passed a further ordinance to permit trustees to offer no more than one hour of French instruction per day beyond the grade 3 level, or instruction in a language other than

8. Rév. Père H. Leduc, o.m.i., Hostilité démasquée. Territoires du Nord-Ouest. Ordonnance Scolaire No. 22 de 1892 et ses néfastes conséquences (Montréal: C. O. Beauchemin \& Fils, 1896); Yvette T. M. Mahé, "L’idéologie, le curriculum et les enseignants des écoles bilingues de l'Alberta, 1892-1992," La revue canadienne des langues vivantes 49, 4 (1993): 687-703.

9. To obtain a First-Class Certificate, for example, teacher candidates were examined on the content of books and subject matter such as: "Littérature Française et Anglaise; Grammaire Française de l'Académie; Rhétorique et Composition; Histoire d'Angleterre (Drouin); Histoire du Canada (Garneau); Éléments de Physique; Éléments de Botanique (Provencher); Algèbre Géomètrie et Trigonomètrie, Arithmétique en toutes ses parties (Frères des Écoles Chrétiennes); Analyse Grammaticale et logique; Terme des Livres en partie double et en partie simple; Géographie, mathématique, physique et politique (Holmes); Histoire Sainte; Catéchisme de Persévérance.” In Report of the Board of Education, N.W.T. (1885-1886), Provincial Archives of Regina, 15.

10. Barber, "Canadianization Through the Schools of the Prairie Provinces,” 281-94; Cornelius J. Jaenen, Regards sur les Francos-Manitobains (Winnipeg : University of Winnipeg Press, 1976), 33. The language laws passed in 1916 remained in effect until the 1960s at which time they were amended to meet anglophone parents' demands for French-immersion schooling. 
English. These language ordinances were maintained after Alberta became a province in 1905, and they remained in effect until 1968. ${ }^{11}$

Prairie normal schools fitted teachers into an Anglo-Saxon mould and prepared them to teach all school subjects in English. ${ }^{12}$ In 1893, the Northwest Territories government opened the Regina Normal School, ${ }^{13}$ and from 1906 onwards, the Alberta government established normal schools in Camrose, Calgary, and Edmonton. To prepare ethnic teachers, the Saskatchewan and Alberta governments opened two training centres, but these were shortlived. A Training School for Teachers for Foreign Speaking Communities was opened in 1906 in Regina, Saskatchewan, to provide ethnic students with the rudiments of academic and professional preparation in English, and closed a few years later. In 1913, an English School for Foreigners was opened in Vegreville, Alberta to prepare candidates for normal school by teaching them enough English so that they could teach the Department of Education's school curriculum. This school was closed in 1918. ${ }^{14}$ By 1945, all normal schools in Alberta were closed and teacher training was transferred to the University of Alberta. $^{15}$

11. In 1968, under pressure by anglophone parents to establish French-immersion programs, the government amended the School Act to permit French-language instruction in grades 3 through 12 for up to 50 per cent of the school day. In 1976, a further regulation increased French-language instruction to 80 per cent of the school day. See Edmund A. Aunger, "Dispersed Minorities and Segmental Autonomy: French-Language School Boards in Canada,” Nationalism \& Ethnic Politics 2, 2 (1996): 191-215.

12. Robert S. Patterson, "History of Teacher Education in Alberta," in Shaping the Schools of the Canadian West, ed. David C. Jones et al., 192-207.

13. Armand Lavergne, La vérité sur la question scolaire du Nord-Ouest (Montréal: Imprimerie du "Nationaliste," 1907).

14. Barber, "Canadianization Through the Schools of the Prairie Provinces," 281-94; Lupul, "The Schools and French- and Ukrainian-Language Claims in Alberta to 1918," 73-92.

15. Patterson, "History of Teacher Education in Alberta," 192-207. It was only in the 1970s, as a result of demands by Anglophone parents for French-immersion teachers, that provincial governments created pedagogical institutes for training French-language teachers. In the Prairies, Collège Universitaire de Saint-Boniface in Manitoba, and Collège Universitaire Saint-Jean in Edmonton (now Faculté Saint-Jean, University of Alberta) began to offer a Bachelor of Education program in French in the 1970s. 
To be accepted in a normal school before 1945, teacher candidates had to be proficient in reading and writing English. Candidates who were deemed to be deficient in English during their training were not allowed to proceed in the program. ${ }^{16}$ Monique Hébert, who interviewed nineteen Franco-Manitoban women who taught school between 1921 and 1951, found that most of them had been threatened with expulsion when they attended normal school because their professors perceived them to be weak in English. They were referred to as "Frenchies," and some of them were placed in special classes with other ethnic students. "On savait ben parler l'anglais! C’tait just'notr’nom...Tous les chuck, les ski, les Marion, les Lemaire, tout c'qui n'avait pas un nom anglais-anglais passait dans la classe des specials." ${ }^{17}$

Information on Franco-Albertans who attended normal schools in Alberta is sparse. For the period 1907 to 1940 I have found only two Annual Reports which provide statistics on the number of French-Canadians registered in normal schools. The 1936 report states that fourteen German and French-Canadians were attending normal schools, ${ }^{18}$ and the 1937 report mentions that there were ten French-Canadian teacher candidates. ${ }^{19}$ But it appears that yearly demands for French-language teachers in prairie districts before 1940 exceeded the number of French-Canadian normal school graduates. ${ }^{20}$ In a previous study I estimated that between 1908 and 1935 there was a yearly shortage of thirty to fifty bilingual teachers in Alberta. ${ }^{21}$ This finding implies that 30 to 50 per cent of the

16. Department of Education (hereafter DE), Thirty-Third Annual Report of the Department of Education of the Province of Alberta, 1938 (Edmonton: King's Printer, 1939), 21, 34.

17. Hébert, “Vivre sa francophonie au temps de l’illégalité,” 295-316.

18. DE, Thirty-First Annual Report, 1936 (1937), 42.

19. DE, Thirty-Second Annual Report, 1937 (1938), 42.

20. In DE, Thirty-Sixth Annual Report, 1941 (1942), 62; Alexander Gregor and Keith Wilson, The Development of Education in Manitoba (Dubuque: Kendall/Hunt Publishing Co.), 76; Raymond J.A. Huel, L'Association catholique franco-canadienne de la Saskatchewan: Un rampart contre l'assimilation culturelle 1912-1934 (Regina: Les Publications Fransaskoises Ltée., 1969).

21. See Yvette T. M. Mahé, "Bilingual School District Trustees and Cultural Transmission: The Alberta Experience, 1892-1939,” Historical Studies in Education 9, 1 (1997): 65-82. Statistics on these shortages were drawn from newspaper articles, ACFA 
bilingual districts then in existence ${ }^{22}$ had problems finding qualified bilingual teachers. As early as 1896, Rév. Leduc, o.m.i., remarked that trustees in French districts in the Territories were unable to operate their schools because of an increasing shortage of Frenchlanguage teachers. ${ }^{23}$ In a letter he sent to the press in 1908, l'Abbé Bérubé disclosed that there would be a need for fifty competent bilingual teachers in Alberta within two years, but that only ten such teachers would be available. ${ }^{24}$ French-language teacher shortages remained a chronic problem. In 1934, for example, Maurice Lavallée wrote in the press that there was a shortage of forty bilingual teachers. ${ }^{25}$

Francophone elites had noted that a number of FrenchCanadian normal school graduates had accepted positions in English schools for monetary reasons. ${ }^{26}$ One individual was of the view that there would not be a shortage of bilingual teachers in Alberta if these graduates went to teach in bilingual schools, " Il y aurait probablement en Alberta assez d'instituteurs capables d'enseigner dans les deux langues si certains ne préferaient pas donner leurs services aux écoles ou l'anglais seul est enseigné.”27 I was not able to find any studies on the number of francophones who went to teach in English districts.

archival documents, correspondence in school district files, and other sources.

22. Before Alberta became a province in 1905, French settlers in Alberta had already established 18 school districts. An additional 60 were erected during the years 1906-19, 22 from 1920 to 1929, and 18 in the period 1930-39. See Mahé, School Districts Established by French-Speaking Settlers in Alberta: 1885-1939.

23. Leduc, Hostilité démasquée.

24. "Lettres de l'ouest sur l'enseignement du français," Le Courrier de l'Ouest (Edmonton) (hereafter Courrier), 30 avril 1908, 5.

25. “En marge du dernier concours de français,” LS, 15 août 1934, 3.

26. "Lettres au Patriote. Gardons nos instituteurs,” Le Patriote, 5 février 1919, 2; "Concours de français," LS, 11 avril 1929, 8; "Les canadiens-français survivront-ils en Alberta?” LS, 22 juin 1932, 3.

27. “Pourquoi nous manquons d'instituteurs," L'Union (hereafter cited as $L$ ' $U$ ), 14 mars 1929, 1. 


\section{Rural Bilingual Schooling and Teacher Shortages}

Robert Patterson found that between 1937 and 1944 the largest number of students attending normal schools in Alberta came from rural areas. He estimated that in 1937-38, 64 per cent of the student body came from farm homes, and that in 1943-44 this number had increased to 80 per cent. ${ }^{28}$ Before 1940, the majority of the French-speaking population in Alberta lived in rural areas. Assuming that the largest group of francophones who attended normal school also came from rural communities, then was there a sufficient number of francophones completing their secondary schooling in rural French districts to build a pool of future teachers?

Before 1940, seven schools in the villages of Bonnyville, Donnelly, Falher, Guy, Legal, Morinville, and St. Paul offered a bilingual program at the secondary level, and an intermediate program. These schools were mainly staffed by female religious who had opened convents in these villages. ${ }^{29}$ These secondary and intermediate schools, however, were not accessible to francophone children who lived in remote areas, unless their parents could afford to pay their boarding expenses while they attended school.

There are no studies on the number of Franco-Albertans who completed their schooling in rural secondary bilingual schools and pursued a career in teaching. There are however some statistics on teachers and schools in the inspection reports of Father Fortier, the

28. Patterson, "History of Teacher Education in Alberta," 202.

29. Female religious who offered secondary and intermediate bilingual programs in rural French districts before 1940 belonged to the following Orders: Bonnyville S.D. No. 2665 (Soeurs de la Charité d'Evron); Donnelly Consolidated S.D. No. 66 (Soeurs de SteCroix); Falher Consolidated S.D. No. 60 (Soeurs de Ste-Croix); Guy Roman Catholic Separate S.D. No. 30 (Soeurs de la Providence); Legal S.D. No. 1738 (Soeurs Grises); St. Paul S.D. No. 1696 (Soeurs de l'Assomption); Thibault S.D. No. 35 (Filles de Jésus). Female religious who offered only intermediate bilingual programs in rural French districts belonged to the following orders: Arctic S.D. No. 198 (Soeurs de l'Assomption); Beaumont Roman Catholic Separate S.D. No. 741 (Filles de Jésus); Lafond S.D. No. 3304 (Soeurs de Ste-Croix); Plamondon S.D. No. 2696 (Filles de Jésus); St. Aubin Roman Catholic Separate S.D. No. 24 (Soeurs de Ste-Croix), and St. Joseph (Fort Kent) S.D. No. 2664 (Soeurs de Ste-Croix). 
"Visiteur des écoles bilingues,"30 of rural bilingual school districts between 1934 and 1939. Over a period of five years he visited a total of 97 rural bilingual districts and inspected a total of 265 teachers (126 females, 102 female religious, 37 males). ${ }^{31}$ I estimated from the information in his reports that 76 per cent (124) of the 163 lay teachers for whom data were available came from farming communities in Alberta, and that most of them had completed their secondary education in village schools under the tutelage of religious teachers. ${ }^{32}$ These findings, though limited, led me to question how many francophones in rural bilingual school districts were completing their secondary studies before 1940, as this number would have had a major impact on the availability of future teachers.

Census figures show the number of years francophones were schooled, but make no distinction among the number of francophones schooled in religious institutions, English schools, or in rural bilingual schools. For 1936, for example, the census shows

30. Father Joseph Fortier, s.-j. (Société de Jésus), was named "Visiteur des écoles bilingues," (an unofficial inspector) by l'Association canadienne-française de l'Alberta in 1934 to inspect the teaching of French and to oversee cultural transmission in bilingual school districts. He visited rural bilingual schools on a yearly basis and completed extensive reports on the school districts, teachers, and students. For more information on the role of "Visiteurs" in cultural transmission in Prairie districts see Yvette T. M. Mahé, "Official and Unofficial School Inspection as Hegemonic and Counter-Hegemonic Struggle in Prairie Districts before 1940,” Canadian Ethnic Studies 33, 2 (2001): 31-51. 31. See Father Fortier, "Rapports du Rév. Père Joseph Fortier, 1934-1940,” Provincial Archives of Alberta (hereafter PAA), Association canadienne-française de l'Alberta Collection, Accession No. 80.226. Between 1934 and 1939 Father Fortier completed a total of 390 inspection reports when he visited French school districts. Ninety per cent of these districts $(\mathrm{N}=97)$ were situated north of Edmonton (24 per cent in the St. Albert, Morinville and Legal regions, 34 per cent in the St. Paul and Bonnyville regions, 18 per cent in the Falher, Girouxville and McLennan regions, and 14 per cent in the Lac La Biche and Athabasca regions). The remaining ten per cent of the districts were situated south of Edmonton, in the Beaumont and Red Deer regions. Fortier is the only "Visiteur" whose reports I have so far been able to find. I did not include Fortier's reports for 194041 in my analysis in this paper as he ceased inspecting schools during the year because of illness.

32. Fortier, "Rapports 1934-39"; also see Anne Gagnon, "Our Parents did not Raise us to be Independent: Young Franco-Albertan Women, 1890-1940,” Prairie Forum 19, 2 (1994): 169-98. Gagnon, who studied the life histories of 253 Franco-Albertan women before 1940, found that 56 per cent of these women were educated in convent schools. 
that there were fewer francophones (14.28 per cent) who had 10 to 12 years of schooling compared to the total Alberta population (19.25 per cent out of 696,759). ${ }^{33}$ From statistics kept by Father Fortier on the number of students registered in the 97 rural bilingual schools he inspected during 1934-39, I calculated that there were between 3,393 to 3,866 students attending these schools on a yearly basis, and that 2 per cent (59 to 68) of the students were completing their secondary studies, 8 per cent (246 to 343) were at the intermediate level, and the remaining 90 per cent were elementary students. ${ }^{34}$ My tentative conclusions from these limited data are that the lack of publicly funded secondary and intermediate bilingual schools in rural Alberta limited francophones' opportunities to complete their studies. As well, the number of francophones completing their secondary education in village schools under the tutelage of female religious appears to have been insufficient for developing a pool of teacher candidates.

In several articles which appeared in the press between 1920 and 1940, francophone elites worried that too many young francophones in farming communities were leaving school after the elementary level. They pointed out that this phenomenon was having an adverse effect on the availability of teachers and on the French community's socio-economic situation. ${ }^{35}$ A team of researchers who investigated the state of bilingual education in Alberta before 1970 found that in 1950, only 375 students were completing Grades 10-12 in bilingual schools. Evelyne FoexOlson, one of the researchers, concluded that the francophone community would therefore have to depend on a very limited number of graduates who might become future teachers: “C'est

33. "Population et agriculture, 1936," in Recensement des provinces des prairies, 1936, Tableau 69, vol I (Ottawa: Bureau fédéral de la statistique, 1938), 1102-1104.

34. Fortier, "Rapports 1934-39.” According to Department of Education Annual Reports for the period 1934-39, between 34.76 per cent and 36.04 per cent of the total Alberta school population was registered in intermediate and secondary programs: DE, ThirtySixth Annual Report, 1941 (1942), 119; DE, Thirty-Eight Annual Report, 1942 (1944), 86. 35. "Formons et spécialisons notre jeunesse," L’U, 16 août 1928, 1; "Faites instruire vos enfants,” LS, 19 août 1931, 1; "L'importance de faire instruire nos jeunes,” LS, 14 août 1934, 3. 
parmi ce nombre restreint d'étudiants achevant leurs études que se recruteront les futurs professeurs."36

\section{Teacher Certification Policies}

French-district trustees could not depend on a supply of Franco-Albertan teachers to fill positions in their schools. As early as 1899, they turned to Quebec for a supply of French-speaking teachers, ${ }^{37}$ but Department officials failed to recognize Quebec teachers' credentials.

In 1893, the Council of Public Instruction in the Northwest Territories passed a ruling which allowed Protestant teachers who possessed an Ontario or Manitoba certificate issued between 1886 and 1893, or a certificate from McGill Normal School, to exchange it for an equivalent Territorial certificate. However, officials refused to exchange the certificates of Quebec teachers who had been trained in Catholic institutions. ${ }^{38}$

Prairie francophones continually pressed their governments to accept Quebec teachers' credentials, but their requests were ignored. $^{39}$ In 1908, the Hon. M. Rutherford, the Minister of Education in Alberta, promised francophones that his department would allow teachers with diplomas from Laval and JacquesCartier Normal Schools to teach in Alberta without having to attend a provincial normal school or pass an exam, but that promise was never kept. ${ }^{40}$ In 1914, the Hon. J. R. Boyle, Minister of Education, arranged with Professor J. A. Dale of the University of McGill in Montreal to hold exams in English four times a year for Quebec

\footnotetext{
36. Evelyne Foex-Olson, “À la recherche d’une efficacité pédagogique de l’A.E.B.A. au Conseil Français,” in École bilingue ou unilingue pour les franco-albertains? ed. Ousmane Silla, Tome I (Edmonton: Collège Universitaire Saint-Jean, 1974), 442.

37. “La fête de la survivance," in L'Ouest canadien (Edmonton) (hereafter L'OC), 17 août 1899, 1.

38. Lavergne, La vérité sur la question scolaire du Nord-Ouest, 28-30.

39. Hélène Chaput, Donatien Frémont. Journaliste de l'ouest canadien (Saint-Boniface: Les Éditions du Blé, 1977), 121; Huel, L’Association catholique franco-canadienne de la Saskatchewan, 48, 56, 121, 231.

40. “Le français dans l’Alberta,” Courrier, 10 septembre 1908, 4.
} 
diploma holders who wanted to teach in Alberta. The minister stated that when these teachers arrived in Alberta they would be able to obtain a temporary permit, but before they could obtain an Alberta Teaching Certificate they had to attend a normal school to familiarize themselves with the Alberta program of studies. ${ }^{41}$ For instance, when Marcel Denault, B.A., arrived to teach in Alberta in 1914, he had completed classical studies in Quebec and had taught school for four years in that province. The Department provided him with a one-year permit to teach in the Grassy Island S.D. No. 3885. The following year he attended the Calgary Normal School and was subsequently awarded an Alberta Teaching Certificate. ${ }^{42}$

In 1924, the Hon. J. R. Boyle told francophones that the Department would recognize diplomas from Catholic institutions in Quebec, but only on condition that graduates possessed sufficient English to conduct a school. The minister added that these teachers had to pass an exam in English to obtain a temporary permit to teach in Alberta, and in order to qualify for an Alberta Teaching Certificate they would be required to spend at least five months in a normal school. ${ }^{43}$ When Sister Aimée du Divin-Coeur, a graduate of l'École normale de Nicolet, Quebec, arrived to teach in Alberta in 1929, the Department exchanged her Quebec Certificate for an Alberta Third-Class Certificate under the express understanding that she would complete a four-month normal school program within two years. ${ }^{44}$

According to Cornelius J. Jaenen, Quebec teachers seemed increasingly unwilling to come west as they had to learn English before they could be certified to teach. ${ }^{45}$ There are no studies showing how many bilingual school teachers originated from Quebec. From a data base I developed which contains the names

41. “L’école bilingue en Alberta,” Le Progrès Albertain, 17 sept. 1914, 1.

42. Isabelle Brosseau, ed., "Grassy Island S.D. No. 3885,” in Souvenirs, Saint-Vincent 1906-1981 (Saint-Vincent: Saint-Vincent Historical Club, 1981), 459.

43. "Les diplômes de Québec seront reconnus en Alberta," Courrier, 21 mai 1924, 1.

44. Soeurs de l'Assomption, "Mission de Wetaskiwin Chroniques 1910-1964,” 29 août 1929, PAA 73.80 SASV/10/9.

45. Cornelius J. Jaenen, “The Manitoba School Question: An Ethnic Interpretation,” in Ethnic Canadians: Culture and Education, ed. Martin L. Kovacs, 317-30. 
of 452 lay teachers (316 females, 116 males and 20 unknown) who taught in bilingual school districts in Alberta between 1885 and $1939,{ }^{46}$ combined with information I found for 183 teachers in school district files, local histories, and French newspapers, I estimated that 13 per cent (24) of these teachers, all females, came from Quebec. From the data Father Fortier recorded in his reports on rural bilingual teacher backgrounds for the period 1934-39, I calculated that 11 per cent (29) of the teachers $(\mathrm{N}=265)$ were from Quebec, and that out of this group the majority (25) were female religious. ${ }^{47}$ These data, though limited to a small sample of bilingual teachers, suggest that lay teachers from Quebec were probably discouraged from going west because of the lack of portability of their diplomas. In addition, they had to be competent in English to obtain an Alberta Teaching Certificate.

There is evidence in school district files that French-district trustees hired a number of teachers from Quebec who were not qualified to teach in Alberta. However, when inspectors discovered that these teachers did not possess an Alberta permit or teaching certificate they forced trustees to dismiss them on the pretext that the children were not progressing in English. ${ }^{48}$

\section{Francophone Associations and the Creation of a Parallel System of Education}

Francophone associations such as l'Association d'éducation des Canadiens français du Manitoba, founded in 1916, l'Association Catholique franco-canadienne de la Saskatchewan, founded in 1912, and l'Association canadienne-française de l'Alberta (hereafter ACFA), founded in 1925, established a parallel

\footnotetext{
46. Yvette T. M. Mahé, School Districts Established by French-Speaking Settlers in Alberta: 1885-1939. The Teachers, vol. II (Edmonton: Faculté Saint-Jean, University of Alberta, 1991).

47. Fortier, "Rapports 1934-39."

48. Inspector to M.W. Gorman, 25 Nov. 1920, Donnelly S.D. No. 66, PAA, 84.37/1817a, b; Minutes of Meetings, 1 Apr. 1907 to 8 Jan. 1936, St. Laurent S.D. No. 1614 (8 May 1911), PAA 73.248.50; “À l'école Boudreau,” L’U, 17 février 1927, 4.
} 
system of education to help curb francophone assimilation in French districts.

These associations created a French program of studies, they organized French exams (concours de français) to ensure that francophone goals of schooling were being met, and they named «Visiteurs d'écoles » to oversee the teaching of French and cultural transmission in French districts. ${ }^{49}$ They also assisted teachers and trustees in organizing professional associations. In Alberta, ACFA helped in the formation of l'Association des instituteurs bilingues de l'Alberta in 1926, and l'Association des commissaires d'écoles de langue française de l'Alberta in $1935 .^{50}$

Association members were concerned that the majority of bilingual school teachers had not been properly schooled in French to teach in that language. In the 1930s, they therefore began to offer summer courses in the teaching of French, Religion, and French-Canadian History. ${ }^{51}$ By 1936, ACFA had succeeded in obtaining from the department a pedagogical course in the teaching of primary French which was taught at the University of Alberta. This course could be credited towards a teacher's First-Class Certificate. $^{52}$

To encourage young francophones to pursue a career in teaching, ACFA instituted a system of bursaries in the 1930s to be awarded to Concours de français laureates so that they could attend normal school. ${ }^{53}$ In 1928, the Filles de Jésus in Morinville, Alberta, began to offer courses in the pedagogy of teaching to

49. Chaput, Donatien Frémont. Journaliste de l'ouest canadien, 109-30; Hébert, "Vivre sa francophonie au temps de l'illégalité,” 295-316; Mahé, "Bilingual School Teachers' Cultural Mission and Practices in Alberta before 1940,” 135-63; Mahé, “Official and Unofficial School Inspection,” 31-51; Mgr. Emile Yelle, p.s.s., "La langue et l'esprit français dans le Manitoba et dans l'ouest canadien,” in Deuxième congrès de la langue française au Canada, 1937. Compte rendu (Québec: L'Action catholique, 1938), 224-43. 50. “Colonne de l'Association canadienne-française de l'Alberta," $L$ ' $U$, 8 septembre 1927, 1.

51. "Cours de français pendant l'été,” LS, 21 juin 1933, 1; “Cours de pédagogie de l'ACFA,” LS, 23 mai 1934, 1.

52. “Un cours de pédagogie française à l’Université de l’Alberta,” LS, 15 avril 1936, 3. 53. "Bourses d'école normale,” LS, 20 novembre 1930, 2; "Les bourses du concours de français de l'ACFA,” LS, 23 juillet 1931, 1. 
young women. Needless to say, their courses were not recognized for accreditation by the Department of Education. ${ }^{54}$

Regardless of elites' efforts to promote teaching as an important career for francophone cultural survival, the insignificant amount of French instruction allowed by law in French districts prevented young Franco-Albertans from becoming proficient enough in French so that they could teach in that language. In 1914, L. A. Giroux feared that francophones' struggles would be in vain if they did not have dedicated and nationalist teachers willing to expand the laws governing the teaching of French: “Toutes nos espérances seront vaines et nos conquêtes inutiles si nous n’avons des maîtres diplomés, éclairés, capables de prolonger les heures de classes légales ou des les employer fructueusement."55 In 1935, a nun who taught secondary school in the Donnelly Consolidated S.D. No. 66 explained to Father Fortier that her students had the necessary religious convictions to make good teachers, but they were too weak in French to compete for normal school bursaries which would have enabled them to pursue a career in teaching. ${ }^{56}$

\section{Impact of Bilingual Teacher Shortages in French Districts}

In the late 1890s, French-district trustees began to have problems finding qualified bilingual teachers. ${ }^{57}$ In 1908, l'Abbé Bérubé predicted that bilingual teacher shortages would force trustees to hire English and Protestant teachers: "Il arrivera que dans nos écoles à nous, nous serons forcés d'engager des

\footnotetext{
54. "Morinville, établissement de cours de pédagogie française au Couvent NotreDame," L'U, 24 mai 1928, 4; also see Alice Trottier, f.j., and Juliette Fournier, Les Filles de Jésus en Amérique (Charlesbourg, PQ: Imprimerie Le Renouveau Inc., 1986), 216-20. 55. L. A. Giroux, “L’État juridique du français dans l’Alberta,” Courrier, 3 septembre 1914, 7.

56. See Fortier, “Rapports 1934-39,” École Donnelly, visite le 17 mai, 1935, PAA, 80.226 .

57. Leduc, Hostilité démasquée, 12; Jean Pierre, “Correspondance,” L’OC, 28 avril 1898, 1.
} 
professeurs anglais et protestants." 58 From my data on the 118 school districts established by francophones between 1885 and $1939,{ }^{59}$ combined with data from school district files which made reference to non-francophone teachers, I found that 62 per cent (73) of the 118 districts had hired at least one or more non-francophone teachers over the years, and that in 12 of these districts over 50 per cent of the teachers hired were non-francophones. ${ }^{60}$ It goes without saying that the hiring of non-francophone teachers in French districts became a source of tension between trustees, parents, and government and divisional administrators.

Trustees in the Racine S.D. No. 2143 hired three anglophone teachers between 1915 and 1918 to keep their school open. As a consequence, a number of parents kept their children at home. In 1917, Miss Potts wrote in the Monthly Attendance Record she had submitted to the Chief Attendance Officer that " the French people don't want to send their children to English Speaking school. Will you please notify them." ${ }^{61}$ In 1922, the trustees of Fremont S.D. No. 3297 had turned down an English teacher recommended by the Department. Officials were concerned that "leaving the thirty children in the district without an opportunity to receive at least some education” was problematic, so they decided to "step in and appoint an official trustee in order to protect the interests of the children." ${ }^{\text {"2 }}$ Between 1921 and 1931 trustees in the Ste Cecile S.D. No. 3377 kept their school closed because they could not find a bilingual teacher. Yet minutes of meetings for that period show that they had advertised for a bilingual teacher in the Bulletin, in

58. “Lettres de l'ouest sur l'enseignement du français,” Courrier, 20 avril 1908, 4.

59. Mahé, School Districts Established by French-Speaking Settlers in Alberta: 18851939. Identification of Bilingual School Districts.

60. The 12 bilingual school districts who had hired more than 50 per cent of nonfrancophone teachers are as follows: Belanger S.D. No. 4471; Bellerive S.D. No. 4175; Berney S. D. No. 3937; Bouvier S.D. No. 3308; Charest Roman Catholic Public S.D. No. 51; Charron S.D. No. 4424; Gauthier S.D. No. 4452; Jeanne D’Arc S.D. No. 2205; Plante S.D. No. 481; Racine S.D. No. 2143; St. Eugene S.D. No. 719; Tangent S.D. No. 4474. 61. Attendance Report from S. M. Potts to Mr. O’Brien, 1917, Racine S.D. No. 2143, PAA 75.126/4893, 84.37/1293 a, b.

62. H. J. Spicer, Registrar to X. P. Crispo, 1 June 1922, Fremont S.D. No. 3297, PAA 84.34/2404a. 
Franco-Albertan newspapers, and in La Presse, Montréal. In the meantime the children were boarded in other French districts, but this created a financial burden on the parents. In 1931, the Department sent an anglophone teacher to reopen the school. ${ }^{63}$

When trustees asked the Department to send them a bilingual teacher, officials generally responded that it was doubtful that such a teacher could be secured. In 1941, for example, the Chief Superintendent of Schools replied to Father Bourque of the Tangent S.D. No. 4474 that

neither the Edmonton Normal School nor the Calgary Normal School, however, have a bilingual student whom they can send out. We are attempting, however, to secure an English speaking teacher of the Catholic faith to take charge of the junior room in the Tangent schools. We should be glad to send you a bilingual teacher if one were available but such not being the case, we are attempting to do the next best thing, that is, to send a teacher of the Catholic faith. ${ }^{64}$

There are no studies of the number of non-francophone teachers who taught in bilingual school districts between 1890 and 1940. Of the 452 lay teachers who taught in bilingual districts between 1885 and 1939, I estimated that 184 teachers (41 per cent) were non-francophones, ${ }^{65}$ but when I analyzed data originating from Father Fortier's reports for the period 1934-39, I found that only 20 per cent of the lay teachers who taught in rural bilingual districts were non-francophones. ${ }^{66}$ These findings are tentative as there may be other archival information on teachers to be unearthed.

63. Minutes of Meeting, December 1916 to December 1938, Ste Cecile S.D. No. 3377, PAA 68.278, 68.279, 644.

64. Chief Inspector of Schools to Father Bourque, 31 Dec. 1941, Tangent S.D. No. 4474, PAA 84.37/3544c.

65. Mahé, School Districts Established by French-Speaking Settlers in Alberta: 18851939. The Teachers.

66. Fortier, "Rapports 1934-39.” 


\section{French District Consolidation and Administrators' Practices}

The major question which arose in French districts after their consolidation was : who was responsible for hiring teachers? In 1952, H.E. Balfour, the Director of School Administration, sent a letter to the Secretary Treasurer of the St. Paul School Division No. 45 which stated :

Appointment of teachers is the responsibility of the Divisional Board, but Section 383, subsections 2 and 3, and Section 389 (2) give the local board certain rights which these subsections of the Act have been interpreted as providing that the local board may nominate a sufficient number of teachers to take care of the teaching of French and religion. ${ }^{67}$

In a number of French districts divisional administrators disregarded francophones' requests for a bilingual teacher. In 1953, when the trustees of La Corey S.D. No. 4425 complained to the Department that a French-speaking teacher was placed in an English-speaking rather than a French-speaking classroom, W.E. Frame, the Chief Superintendent of Schools, responded that "the divisional board has full power to act as the local board has no jurisdiction in the matter of rooms to which teachers are assigned." 68 In the Tangent S.D. No. 4474 the secretary of the district sent a letter to the Minister of Education in 1952 informing him that the teaching of French at school was being neglected, "because the teacher, Mrs. N. Lambright refuses to exchange duties with another teacher capable of teaching French."69 In the Dunrobin S.D. No. 3484 there was a lock-out by French parents at the school when a Protestant teacher was hired in 1958. In his

67. H.E. Balfour, Director of School Administration, to Mr. Yves Dupuis, Secretary Treasurer, St. Paul School District No. 45, 14 July 1952, PAA 84.37/1457a.

68. W. E. Frame, Chief Superintendent of Schools, to Rev. J. Lavergne, Secretary, 17 Dec. 1953, La Corey S.D. No. 4425, PAA 84.37/3495a.

69. Donat Sylvestre, Secretary, to Hon. Anders Aalborg, Minister of Education, 4 dec. 1952, Tangent S.D. No. 4474, PAA 84.37/3544c. 
letter to the Chief Superintendant of Schools, the Divisional Superintendent explained his perception of the situation as follows:

You may recall that we had a lock-out when one Protestant teacher was put on the staff at Dunrobin school at Vimy. Although I am sure practically no one would believe me, the Protestant teacher was not put on to establish a precedent or to give Protestant parents a teacher of their own faith. She was put on that staff because she was the only teacher available. ${ }^{70}$

\section{Working Conditions and Transiency in French Districts}

Anglo-dominant educational institutions, government policies, and divisional administrators' practices had an impact on the creation and maintenance of bilingual teacher shortages before 1960, but other factors such as working conditions and teacher transiency also affected teacher shortages.

In comparison to their counterparts in English districts, teachers who taught in French districts had a double workload as a result of the demands of two separate cultural communities competing for legitimacy for their language and world-view. But were these teachers compensated accordingly? How did the working conditions in bilingual districts affect their retention?

\section{Teacher Workload}

Teachers were required by law to teach the English program of studies. This meant that they were expected to teach thoroughly the English language, to familiarize pupils with the growth and development of the British Empire, and to foster in children

70. Earle G. McDonald, Superintendent, Westlock S.D. No. 37 to Dr. T. C. Byrne, Chief Superintendent of Schools, 17 Dec. 1958, Dunrobin S.D. No. 3458, PAA 84.37/2575a. 
patriotic and imperial sentiments. ${ }^{71}$ When state inspectors visited bilingual schools they evaluated teachers on the basis of their ability to help children progress in English. ${ }^{72}$ On the other hand, the French community expected teachers in bilingual districts to be the guardians and saviours of the French language and models of Catholic patriotism, and to help children develop patriotic FrenchCanadian sentiments rather than an English patriotism. "Visiteurs d'écoles" assessed them on their ability to teach French and transmit the French-Canadian heritage, and parish priests tested children's knowledge of catechism. ${ }^{73}$ Teaching in French districts was a formidable task, but there are indications in the press that teachers did not always have parental support, nor, for that matter, the support of school trustees. ${ }^{74}$ Furthermore, in districts with changing demographics, teachers were faced with mounting pressures from non-francophone parents or trustees to reduce or eliminate French or religious instruction from their curriculum. ${ }^{75}$

\section{Salaries and Gender}

A resolution passed at an ACFA Convention in 1933 stated that trustees should consider renumerating bilingual teachers in proportion to their workload: "Que les commissaires scolaires considèrent qu'un instituteur bilingue a un surcroît de travail et veuillent le rémunérer proportionnellement."76 This resolution implies that teachers in French districts were not being properly rewarded for the dual role they played in cultural transmission.

71. DE, Annual Report of the Department of Education, 1906 (1907), 70; DE, Twelfth Annual Report, 1917 (1918), 57.

72. Mahé, “Official and Unofficial School Inspection,” 31-51.

73. Mahé, “Bilingual School Teachers’ Cultural Mission and Practices in Alberta Before 1940,” 135-63.

74. “Colonne de l'ACFA. Commissaires d'écoles,” L’U, 31 mars 1927, 1; "Et vos enfants?” LS, 11 juillet 1934, 7; “Au congrès des commissaires,” LS, 10 février 1937, 1, 5.

75. Mahé, “Bilingual School Teachers' Cultural Mission and Practices in Alberta before 1940,” 135-63.

76. “Congrès A.C.F.A. Résolutions,” LS, 19 juillet 1933, 8. 
The information on teachers' salaries in bilingual district files was too sparse for me to analyze. I therefore used the data on teachers' salaries recorded by Father Fortier for the period 1934-39 to verify if bilingual teachers received any special compensation for their double workload. I found that for four years out of five the average yearly salaries paid to 95 lay teachers who taught in bilingual districts were one per cent higher than the average yearly salaries paid to all rural teachers in Alberta. ${ }^{77}$ The one per cent difference in favour of bilingual teachers is attributable to male teachers, and to seven female religious who were principals of secondary schools, receiving the highest salaries in the $\$ 840$ (statutory minimum) to $\$ 1,100$ range. The lowest salaries in the $\$ 600$ to $\$ 690$ range were paid to females who taught in 26 of the poorer French districts situated in remote or recently settled areas. Department reports confirm that teachers' salaries became progressively lower in poorer and more remote districts. ${ }^{78}$

Females, who constituted the majority (86 per cent) of the teaching staff (126 females, 102 female religious and 37 males) in bilingual districts between 1934 and 1939 were not properly compensated for their dual role in cultural transmission; their salaries were between 5 and 11 per cent lower than those paid to male teachers. ${ }^{79}$ According to the literature, female teachers in other rural Canadian settings before 1940 also outnumbered males by anywhere between 70 and 80 per cent; their salaries were also lower than those paid to male teachers. ${ }^{80}$

77. Average yearly salaries paid to rural teachers in Alberta for four years were the following: 1934-35, \$723; 1935-36, \$731; 1937-38, \$778; 1938-39, \$789. DE, TwentyNinth Annual Report, 1934 (1935), 109; Thirtieth Annual Report 1935 (1936), 97; ThirtyFirst Annual Report, 1936 (1937), 100; Thirty-Second Annual Report, 1937 (1938), 99; Thirty-Third Annual Report, 1938 (1939), 115.

78. DE, Twenty-Eight Annual Report, 1933 (1934), 52.

79. Fortier, "Rapports 1934-39."

80. For more information on the dominance of females in teaching and their lower salaries compared to male teachers, see Jean Barman, "Birds of Passage or Early Professionals? Teachers in Late Nineteenth-Century British Columbia,” Historical Studies in Education 2, 1 (1990): 17-36; Thomas Fleming, Caroline Smyly, and Julie White, "Lottie Bowron Within Organizational Realities and Bases of Power: British Columbia, 1928-1934,” Journal of Educational Administration and Foundations 5, 22 (1990): 7-31; Monique Hébert, "Une question de survie: Épisodes de la vie des femmes francophones 


\section{Teacher Retention in Bilingual Districts}

The rate of teacher turnover in rural Canadian school districts before 1940 was quite high. Teachers migrated from one district to another almost on a yearly basis in search of better salaries and working conditions. ${ }^{81}$ John W. Chalmers explains that in the past, rural teachers in Alberta have generally been highly mobile. ${ }^{82}$ If bilingual teachers were as migratory as their counterparts in other settings, how did their transiency affect schooling in bilingual districts?

The bulk of school district revenues in most Canadian districts before 1940 came mainly from local taxation. ${ }^{83}$ When farming families experienced poor crop yields due to inclement weather, or when the price of wheat was low, they were unable to pay their school taxes. Without a stable tax base, trustees in 33 rural bilingual school districts (out of 118) had problems recruiting and

du Manitoba, de 1916 à 1947," in Entre le quotidien et le politique: Facettes de l'histoire des femmes francophones en milieu minoritaire, Monique Hébert, Nathalie Kermoal, et Phillis Leblanc, dir. (Gloucester: Réseau national d'action éducation femmes, 1997), 5174; David C. Jones, "Creating Rural Minded Teachers: The British Columbia Experience, 1914-1924," in Shaping the Schools of the Canadian West, ed. David C. Jones et al., 15578; Robert S. Patterson, "Voices from the Past: The Personal and Professional Struggle of Rural School Teachers,” in Schools in the West: Essays in Canadian Educational History, ed. Nancy M. Sheehan, J. Donald Wilson, and David C. Jones (Calgary: Detselig, 1986), 99-111; Cecilia Reynolds and Harry Smaller, "Gender Relations Among Teachers: A Study of Ontario Teachers in the 1930s," Revue des sciences de l'éducation de McGill 31, 1 (1996): 39-55; Kate Rousmaniere, "Teachers' Work and the Social Relations of School Space in Early-Twentieth-Century North American Urban Schools,” Historical Studies in Education 8, 1 (1996): 42-64.

81. For more information on the factors underlying teacher transiency see Barman, "Birds of Passage or Early Professionals?” 17-36; Marta Danylewycz and Alison Prentice, "Revising the History of Teachers: A Canadian Perspective," Interchange 17, 2 (1986): 135-46; Gagnon, "Our Parents did not Raise us to be Independent," 169-88; Fleming, Smyly, and White, "Lottie Bowron Within Organizational Realities and Bases of Power: British Columbia 1928-1934,” 7-31; Dianne M. Hallman, “A Thing of the Past: Teaching in One-Room Schools in Rural Nova Scotia, 1936-1941," Historical Studies in Education 4, 1 (1992): 113-32.

82. John W. Chalmers, Schools of the Foothills Province (Toronto: University of Toronto Press, 1967), 130.

83. Harry T. Sparley, “A History of the Alberta School System to 1925 ” (Ph.D. diss, University of Alberta, 1958), 189-91. 
retaining teachers during the period 1885 to 1939 as they could not offer them attractive salaries and working conditions. These districts were also indebted to a number of teachers several years after they had left the district. ${ }^{84}$ According to Department reports, in poorer areas school districts were generally in debt to as many as three or four teachers. ${ }^{85}$ Financial problems in bilingual districts were more prevalent during the Depression years of 1929 to1931. For instance, in 1931, an article in the French press asked the francophone community to donate clothing and bedding to the Girouxville settlers who were on relief and needed these items for the winter season. ${ }^{86}$ Poverty in this area affected the Girouxville S. D. No. 4353's revenues. Minutes of meetings for June, 1932 show that trustees had requested a loan from the Department to pay the balance of the teacher's salary as it was impossible for them to collect any taxes from the rate payers. ${ }^{87}$

French districts with dire financial problems experienced high teacher turnover. In the Champlain S.D. No. 1776, for example, all nineteen teachers who had been hired by this district between 1909 and 1925 left the district in the middle of the year or at the end of the school year. District records show that on a yearly basis trustees had requested loans to pay its teachers a portion of their salaries. ${ }^{88}$ Roméo Lamothe, who taught at La Corey S.D. No 4424 in 1935, found the working conditions and cultural expectations in a French district to be arduous and tedious. He had to teach in two languages, provide religious instruction to 46 pupils in eight grades, and write all the notes and assignments on the board for pupils to copy as he did not have enough textbooks in French. The contract he had signed with this district specified that he would be paid $\$ 700$ a year, but when he did not receive his salary he was

84. Mahé, "Bilingual School District Trustees and Cultural Transmission: The Alberta Experience, 1892-1939,” 65-82.

85. DE, Thirtieth Annual Report, 1935 (1936), 55-56; Minister of Education, What is and what Plight be in Rural Education in Alberta (Edmonton: Minister of Education, 1935), 4.

86. “Girouxville,” LS, 9 décembre 1931, 8; “Girouxville,” LS, 23 novembre 1932, 5.

87. Minutes of Meeting, 2 June 1932, Girouxville S.D. No. 4352, PAA 84.37/3422 a-c.

88. Minutes of Meeting, 1909 to 1925, Champlain S.D. No. 1776, PAA 84.37/929. 
forced to pay for his groceries with IOUs, and in turn the shopkeeper gave the IOUs to the school board in partial payment of his taxes. Mr. Lamothe left the school district at the end of the year, but he did not receive the balance of his salary until seven years later. ${ }^{89}$

From my data base, I estimated that out of 432 teachers for whom sufficient data was available, 78 per cent of the female teachers $(\mathrm{N}=316)$ and 79 per cent of the male teachers $(\mathrm{N}=116)$ appear to have spent a year or less in one district. ${ }^{90}$ As well, when I analyzed the data from Father Fortier's reports for the period 1934-39, I found that 53 per cent of the lay teachers $(\mathrm{N}=109)$ who taught in rural bilingual districts had moved to another district or left teaching after one year. ${ }^{91}$ This percentage is similar to the yearly turnover rates of 50 to 56 percent in other rural Alberta districts for the same years. ${ }^{92}$ From the data in Father Fortier's reports I traced the career paths of 95 lay female and male teachers over a period of five years and found that only 15 per cent (all females) of the teachers had remained in the same district for five years. I also noted that on the average, female teachers changed school districts every two to three years whereas most males migrated from one district to another on a yearly basis. However, the transiency rate for female religious was quite low as only nine of them (out of 102), all Soeurs de Ste Croix, had moved to another village school under the tutelage of their religious order. ${ }^{93}$

On account of teacher transiency, French district trustees were continually faced with having to find bilingual teachers. But due to their scarcity, trustees had no recourse but to hire nonfrancophone teachers to keep their schools open.

89. La Corey Historical Committee, Coal Oil to Crude: Iron River (Edmonton: Friesen Printers, 1980), 135.

90. Mahé, School Districts Established by French-Speaking Settlers in Alberta: 18851939. The Teachers.

91. Fortier, "Rapports 1934-39."

92. Minister of Education, What is and what Plight be in Rural Education in Alberta, 4; DE, Thirty-First Annual Report, 1936 (1937), 55-56.

93. Fortier, "Rapports 1934-39." 


\section{Impact of Bilingual Teacher Shortages on Cultural Continuity}

In 1936, a Department report stated that the lack of continuity of teachers in rural districts was detrimental to the educational progress of pupils. ${ }^{94}$ The high rate of teacher turnover in bilingual school districts affected not only students' academic progress, but limited them in formally learning French and developing an ethnic identity.

There are several transcripts of interviews with Alberta pioneers in the Héritage Franco-Albertain collection which illustrate the impact of Anglo-dominant schooling on francophones' learning experiences. For instance, when she was interviewed in the 1970s, Mme. Chartrand spoke about what it was like when she started school in Bonnyville in the 1920s. She remembered that the students were all francophones, but there were no French teachers at her school because trustees could not find any. She found her first school year in English to be difficult and, as a result, she did not begin to read until sometime during her second school year: "C’était extrêment dur. La première année, moi, j’ai pas appris à lire. La deuxième année, j’ai commencé à essayer." "95 I noted in the transcript notes that she never completed her elementary schooling.

Father Fortier told ACFA members in 1934 that he had observed that on account of the English ambience in schools, English was natural for young French-Canadians, and that it was becoming their national language and French a foreign language; “...l'anglais devient si naturel à nos petits canadiens-français, qu'elle [sic] est pratiquement pour eux la langue nationale et que le français est menacé d'être à leurs yeux une langue étrangère."96 In the 1930s Hermas Bastien studied the teaching of French in bilingual schools in Alberta and found that the teaching of French

94. DE, Twenty-Ninth Annual Report, 1934 (1935), 55.

95. Denise Rougeau-Kent, “Interviews with Mme Jeanne Chartrand, 1901-1978,” (Edmonton: Faculté Saint-Jean, Institut de recherche, 1978), HERI.TRANS H54H55/DRK1-2.

96. “Et vos enfants?” LS, 11 juillet 1934, 7. 
was deplorable at the primary level as students were poorly prepared lingualistically, and he also noticed that more advanced students had problems writing in French. Their schooling, he concluded, brought no vitality to the French language, “n’apporte guère de tonique, de cordial, de vitamines." 97 In a major study conducted in the 1970s on the state of bilingual education in Alberta, the principal researcher, Ousmane Silla, linked young Franco-Albertans' linguistic problems to anglophone teachers who had only the rudiments of French. He stated that as a result of the poor quality of French being perpetuated in bilingual schools, the French language was becoming creolized: "nous allons de plus en plus vers un appauvrissement du français parlé par les FrancoAlbertains; vers une certaine créolisation, un "broken French" ou "Pidgin French.... qui se répandra par les écoles."98 In recent years, a number of researchers have concluded that Anglodominant schooling has greatly affected the intergenerational assimilation of francophones. ${ }^{99}$

97. Hermas Bastien, Le bilinguisme au Canada (Montréal: Éditions de l’ACF, 1938), 128.

98. Ousmane Silla, ed., "Les écoles bilingues," École bilingue ou unilingue pour les franco-albertains? vol. II (Edmonton: Collège Universitaire Saint-Jean, l’Université de l'Alberta, 1974), 176.

99. For statistics and information on assimilation of francophones outside Quebec see Aunger, "Dispersed Minorities and Segmental Autonomy: French-Language School Boards in Canada," 191-215; Roger Bernard, "Les contradictions fondamentales de l'école minoritaire," Revue des sciences de l'éducation 23, 3 (1997): 509-26; Charles Castonguay, "La montée de l'anglicisation chez les jeunes Franco-Ontariens," Bulletin du Centre de recherche en civilisation canadienne-française de l'Université d'Ottawa 12 (1976): 5-7; Castonguay, "Évolution de l'assimilation linguistique au Québec et au Canada entre 1971 et 1991," Recherches sociographiques 38, 3 (1997): 469-90; Rodrigue Landry, Réal Allard, and Raymond Théberge, "School and Family: French Ambiance and the Bilingual Development of Francophone Western Canadians," The Canadian Modern Language Review 47, 5(1991): 878-915; Bruno Ouellette, L'analphabétisme chez les franco-albertains (Edmonton: Éducation permanente, Faculté Saint-Jean, Université de l'Alberta, 1990). 


\section{Conclusion}

After the state took over control of schooling in the prairies in the 1890s, education became a political matter. To transmit their concept of the world and unify all ethnic groups, Anglo-dominant governments used the law as an instrument to bring about uniformity of the use of the English language in schools, in teacher training institutions, and as a basis for certifying teachers. These institutional practices resulted in the creation and maintenance of bilingual teacher shortages until the 1970s. Notwithstanding francophones' resistance to norms of schooling established in Anglo-Canadian culture, their interests were nonetheless subordinated by government officials as well as by divisional administrators who were unwilling to recognize their ethnic diversity.

Bilingual school teachers, perceived by francophone elites as the guardians of the French language and culture, received no special renumeration for the dual role they played in cultural transmission. In addition, a number of them worked under deplorable conditions because of impoverished economic situations. The problem of bilingual teacher shortages was aggravated by the frequent turnover of teachers seeking better working conditions and salaries elsewhere. Trustees had problems replacing bilingual teachers who left. When they hired nonfrancophone teachers to keep their schools open, francophone cultural continuity was threatened.

This study of bilingual or French-language teacher shortages in the past sheds light on a number of interwoven socio- political factors which seriously hampered francophone cultural transfer. Although in the last twenty years there have been a number of political, legal, and institutional transformations which have given French-speaking minorities outside Quebec the right to educate their children in French and to manage their schools, the pervasiveness of French-language teacher shortages has not been 
resolved. ${ }^{100}$ The state continues to influence teacher education institutions through its financial policies. Therefore it would be fruitful to investigate the impact of the limited number of Frenchlanguage universities outside Quebec on French-language teacher shortages. Studies are presently being conducted in several provinces to discover why a large number of francophone and French-immersion students abandon French programs and transfer into an English program once they reach high school. ${ }^{101}$ This phenomenon certainly deserves to be investigated as this movement towards English secondary schools reduces the pool of potential French-language teachers.

100. For more information on French-language teacher shortages in French-immersion and in francophone minority milieux, see Canadian Parents for French, "L'État de l'enseignement du français langue seconde," in Le Canada de l'an 2002 (Ottawa: Canadian Parents for French, 2001), 19; Sarah Hood, "Teacher Shortages Threaten the Quality of French Programs,” Language and Society 39 (1990): 32-33; “Grave pénurie d'enseignants dans les communautés francophones hors Québec, Le Franco, 6 au 12 avril 2001, 2; "Pour contrer la pénurie des enseignants: Valoriser la profession, améliorer les conditions de travail,” Le Franco, 13 au 19 avril 2001, 2; Charlotte Ouellet, Secretary General and Treasurer of l'Association canadienne d'éducation (ACELF), 29 Jan. 2002, http://www.acelf.ca

101. Canadian Parents for French, “L’État de l'enseignement du français langue seconde," 4-5, 8. 